\title{
Towards an open Marxist theory of imperialism ${ }^{1}$
}

\section{Alex Sutton}

\begin{abstract}
The purpose of the paper is to provide the basis for a theory of imperialism that is consonant with open Marxism. The need for an open Marxist theory of imperialism derives from two sources: firstly, a critique from open Marxism of extant theories of imperialism that they treat contingent factors as necessary elements of imperialism. Secondly, and certainly a less theoretical point, is the obvious and intuitive value of an account of imperialism. Where states compete to immobilise capital within their own territory, this leads to unequal relationships between states, one of which is imperialism. It is essential to understand what the nature of this relationship is if we are to understand capitalism on a global scale, which is to say at all. This can only be accomplished by understanding what the state is, how it is constituted and what its function is within society. Open Marxism is particularly well placed to accomplish this. The paper argues that accounts of imperialism heretofore have been contingent and focused on the appearance of imperialism and spent little time considering its essence as a manifestation of the state's power and desire to maintain the circuit of capital both nationally and internationally. The paper then seeks to show that open Marxism is well placed to achieve this and to move towards an idea of an open Marxist theory of imperialism.
\end{abstract}

\section{Introduction}

The enduring nature of imperialism requires that a theory of imperialism will be perennially useful in demystifying its origins and qualities. This paper seeks to show that an open Marxist (OM hereafter) approach is valuable in identifying the necessary qualities of imperialism and its origins in the capitalist social form. Theories of imperialism rest on a theory or conception of the state, which is where OM's contribution to social theory is most robust. The purpose of this paper is to move towards an OM account of imperialism and to identify the basic form of a theory of imperialism that is consonant with OM. The paper argues that extant theories of imperialism are dissonant with OM based upon their conceptions of the state, and social relations more broadly.

The paper first presents an overview of $\mathrm{OM}$, with particular reference to its formanalysis of the state. The paper then provides a critique of classical theories of imperialism, followed by second wave theories and then 'new' imperialist theories. This section argues that these theories have sought to identify the contingent factors of imperialism as necessary factors. The final section argues that an OM theory of imperialism must identify imperialism as fundamentally dynamic in character: the particular and concrete form of imperialism is open while the abstract and general idea of imperialism lies in the nature of capitalist social relations and the capitalist state.

The paper concludes that an OM theory of imperialism, most basically, is the hijacking of one state's capacity to act independently in the interests of capital-in-general. Imperialism is, in essence, a strategy available to states to resolve crises and obstacles to the circuit of capital; its manifestation is ultimately open in character, leading to imperialism's multifarious application. It can be thought of as both a policy undertaken by a 
state, and a relationship between two or more states. However, imperialism is not the exploitation of one state by another but actions undertaken by one national state against another national state to better facilitate the exploitation of global labour by global capital. Nor can it be understood as a stage of capitalism, or the hijacking of a state by a particular fraction of capital (usually described as financial capital). Instead, imperialism springs inherently from the inherent contradictions of capitalism - its crisis-prone character, and its need for ever greater levels of accumulation - and is therefore but one strategy by which the state ensures that capitalist society perpetuates itself.

\section{Open Marxism}

OM's value lies in its critical reappraisal of the class antagonisms between capital and labour, from which the state derives. ${ }^{2} \mathrm{OM}^{\prime}$ 's greatest contribution to the discussion of capitalist social relations is its conceptualisation of the state, providing an account of the state that is more rigorous than either instrumentalist or structuralist accounts of the state, which have tended to be the more common iterations of Marxist state theory (Burnham 1995:95, 2006; Tsolakis 2010:390). Burnham (1995:93) identifies the value of the OM dialectical method, which 'starts with the whole and then searches for the substantive abstraction which constitutes social phenomena as interconnected, complex forms different from, but united in, each other'. This permits a view of society in which the state and the economy do not exist as external or separate entities but as moments within the social relation from which they are both constituted (ibid.).

The term 'open Marxism' characterises the approach in opposition to an analytical 'closure', by which two things are meant (Bonefeld et al. 1992a:xvi). Firstly, closure can refer to an acceptance of the boundaries of a 'given world' as its own theoretical boundaries. Secondly, it can also refer to a determinism, either in a causalist or teleological sense of the word. These two faces of closure are interconnected as 'acceptance of horizons amounts to acceptance of their inevitability and because determinist theory becomes complicit in the foreclosing of possibilities which a contradictory world entails' (ibid.). This closure manifests itself in a number of ways. Of particular relevance to this paper is in regard to the state and historical understandings of capitalism; thus, closure inheres in typologies of states, and in the historical periodization of state-forms and capitalism itself.

Bonefeld (2006:133), in criticism of neo-Gramscian approaches, remarks that the 'periodization of capitalist development will necessarily elevate certain capitalist characteristics to defining qualities of this or that mode of regulation. This procedure tends not only to distract from enduring capitalist features but, also, disconnect us from the lessons of history'. By identifying distinct periods of capitalism, or of the state as a particular kind of state in a historical period, we face the same problem as that of typologies of state. A quote from Francis Herbert Bradley, although ostensibly nothing to do with OM, is a good way to describe this problem.

'Say that the present state of the world is the cause of that total state which follows next on it. Here, again, is... self-contradiction. For how can one state $A$ become a different state B? It must either do this without a reason, and that seems absurd; or else the reason, being additional, forthwith constitutes a new $A$, and so on forever. We have the differences of cause and effect, with their relation of time, and we have no way in 
which it is possible to hold these together. Thus we are drawn to the view that causation is but partial, and that we have but changes of mere elements within a complex whole.' (Bradley 1930:194)

Following from Bradley's point, that state A and state B are entirely illusory and the distinction is fantastical, there is a fundamental unity between all historical periods: distinctions between historical periods are false. As Clarke (1992:149) notes, 'the basis of comparison of successive epochs is the permanence of their contradictory foundations, in the contradictory form of the social relations of capitalist production'. Thus, periodisation is, at most, a historical contingency and therefore capitalism can only be understood as a complex totality (ibid.). To periodise history according to stages of capitalism then is as problematic as identifying different 'types' of states. It is therefore more meaningful to understand phenomena that have previously been called stages of capitalism, as manifestations of the logic of capitalism instead. ${ }^{3}$

More often than not, the concept of form is understood as a type, or species, of a thing; for example, a a state can be seen as a fascist state, or a Fordist state, and so forth. However, the concept of form, as understood by OM is seen as the 'mode of existence: something or other exists only in and through the form(s) it takes' (Bonefeld et al. 1992a:p.xvii). The concept of species-form requires intermediary concepts in order to bridge the gap between the abstract and the particular; for example, how 'the state' become ' $a$ fascist state'. However, form as mode of existence avoids this analytical trap as it 'makes it possible to see the generic as inherent in the specific, and the abstract as inherent in the concrete, because if form is existence then the concrete can be abstract (and vice versa)' (ibid.).

As Burnham (2001a:106) argues, the nature of the state, as a capitalist state, can only be understood in the context of the intrinsic contradictions of the global economy, namely the capitalist mode of production. To understand the state in terms of the conventional theories of International Relations would simply reify the fetishised and fantastical social relations that the state propagates. The state must be seen in terms of its unity with other states, as 'political nodes' processing the circuit of capital within the global capitalist economy (Kettell 2004:22). Thus, as Holloway (1994:36) argues, 'understanding the development of the state cannot be a question of examining internal and external determinants, but of trying to see what it means to say that the national state is a moment of the global capital relation'. ${ }^{4}$

Burnham (2006:80) points out that the relationship between the state and market is complex and one cannot declare a simple causal explanation for state activities based on its relationship with capitalist social relations. Critiquing theories that separate state and market, the political and economic, OM suggests that to do so obscures class antagonisms.. As Marx (1992a:170) noted, a peculiarity about capitalist social relations is that they 'assume a fantastic form different from their reality'. The state as a form of social relations also follows this pattern: 'it is a relation between people which does not appear to be a relation between people, a social relation which exists in the form of something external to social relations... This is the starting point for understanding the unity between states: all are rigidified, apparently autonomous forms of social relations' (Holloway 1994:27). It is necessary to understand states not as separate political entities but through their essential unity; the state is a form of social relations within the capitalist social form, which is itself an 
inherently global phenomenon (Holloway 1994:26). Indeed, as Holloway and Picciotto (1977:80) observe,

'the survival of the political institutions and hence of capital depends on the success of that struggle in maintaining this separation, by channelling the conflicts arising from the real nature of capitalist society into the fetishised forms of the bourgeois political processes. Thus the very separation of economics and politics, the very autonomisation of the state form is part of the struggle of the ruling classes to maintain its domination'.

Class antagonism is inseparable from the reproduction of capitalist social relations. So, capitalism is a fractious and unstable social form, with many specific capitals ostensibly competing among themselves, yet the state's role is to regulate this fractiousness and act on behalf of capital-in-general; this is the only method through which capital expansion can occur generally (Kettell 2004:22.).

The nature of the state then is not to act on behalf of specific capitals, or fractions of capital, but rather on behalf of capital-in-general, as Burnham (2001a:110) notes,

'As political nodes in the global flow of capital, states are essentially regulative agencies implicated in its reproduction but unable to control this reproduction or represent unambiguously the interests of 'national capital'. Rather, state managers seek to remove barriers to the capital which flows in and through their territories. The fundamental tasks of state managers (from welfare to the management of money, labour and trade, etc.) therefore relate directly to ensuring the successful rotation of capital both nationally and internationally.'

The essential elements of an OM theory of imperialism would have to rest upon this basic point about the nature of the state. Most importantly, however, the state is understood as a moment of global capitalist social relations, which is, in its origin a manifestation of capitalism and in its function it is fundamentally tasked with ensuring the successful reproduction of social relations. An OM theory of imperialism must proceed from these two fundamental points.

As such, deriving from the above understanding of the state as a form of social relations, an OM theory of imperialism must accept that the state acts in the interests of capital-in-general, not as a mere tool of capital or in the interests of a single fraction of capital. Nor can the state or capitalism be periodised or typified according to historical contingency or activity; this is not to reject the existence of events or activities that have occurred historically but instead to argue that they can only be understood within the totality of capitalism, as forms of capital social relations.

\section{Classical Imperialism: Finance and Monopoly Capital}

The origins of Marxist understandings of imperialism lie in the early $20^{\text {th }}$ century, and stem from the works of Hobson and Hilferding. While Hobson was not a Marxist himself, his work, along with Hilferding's, provides the foundation for subsequent Marxist theories of imperialism. It is because these authors provide the basis for later theories of imperialism 
that lengthier analysis is dedicated to them. Following from Burnham's (1995:95) point that Marxist theories of the state tend to be either structuralist or instrumentalist, so too do theories of imperialism follow this tendency: either systemic factors, inherent to the capitalist mode of production, initiate a pre-determined imperialist 'stage', or a cabal of financiers turn the state into an instrument of their will. However, with classical theories of imperialism, structuralism and instrumentalism are combined: monopoly capital, which enthrals the state, is a necessary product of capitalist development and initiates imperialism.

Hobson (1968:11), however, unlike subsequent scholars such as Hilferding (1981), Bukharin (2003) or Lenin (2010), characterises imperialism as a perversion of both nationalism and capitalism, and distinct even from colonialism. Hobson's (ibid.) imperialism is an aggressive form of the state geared towards 'territorial and industrial aggrandisement' that transforms the 'wholesome stimulative rivalry of varied national types into the cutthroat struggle of competing empires'. While Hobson's definition here goes some way towards characterising imperialism in normative terms, which is where Hobson's main critique of imperialism lies, it does not provide much of a sustained conceptual analysis of imperialism. Hobson, while not a Marxist, still maintains an analysis with a tendency towards characterising imperialism as a capitalistic enterprise.

Hobson's analysis of imperialism is fractionalist and instrumentalises the state. Hobson's fractionalism maintains that the only reason that the state turns to imperialism is due to sectional interests that usurp the state for their own ends (ibid.:46). Hobson, as with Hilferding, Kautsky and Lenin, identifies these sectional interests as the financiers of capital. $^{5}$

Hobson's theory on the causes of imperialism rests on his development of the notion of under-consumption:

'Everywhere appear excessive powers of production, excessive capital in search of investment... The growth of production... exceeds the growth in consumption, that more goods can be sold at a profit, and that more capital exists than can find remunerative investment' (ibid.:81)

Hobson (ibid.:82) emphasises the fact that it is specifically a problem of underconsumption; that it is a refusal to consume and, in fact, a strong desire to save and invest, rather than a systemic quality of capitalism to tend towards over-production, that precipitates imperial expansion. ${ }^{6}$

'It is, of course, possible that an excess of producing power may exist in particular industries by misdirection... But no one can seriously contend that such misdirection explains the recurrent gluts and consequent depressions of modern industry' (ibid.)

Hobson makes a point that if labour is limited, and if saving is unresponsive to changes in the interest rate, and if production methods remain static, then it is possible for the excessive saving to lead to a depression. Therefore, imperialism is the product of a domestic pressure from capital to find foreign markets in which to invest and sell commodities, using the resources of the state to secure these markets (ibid.:79). It is this manifestation of some form of over-accumulation which characterises both 'classical' and 
newer theories of imperialism, whether it takes the form of Hobson's under-consumption crisis or Luxemburg's (1963) notion of the lack of effective demand, or even Harvey's (2003) acknowledgement of the need to provide 'spatio-temporal fixes' to capitalism's tendency toward over-accumulation.

Hobson's analysis rests on two problematic concepts. Firstly, his fractionalist approach instrumentalises the state and so treats the state as a tool of the interests of a particular section of the dominant class; in this case, the financiers of capital. This approach avoids structural aspects and so can be critiqued that it divorces the state from the society within which it exists. Secondly, Hobson's understanding of the crisis that drives an imperialist agenda as one specifically of under-consumption is erroneous. While underconsumption may well be a feature of a crisis, it is symptomatic of a more fundamental over-production crisis. That a crisis is inherently one of under-consumption is criticised by Hilferding (1981:256) who notes, 'It does not follow at all, therefore, that a crisis in capitalist production is caused by the underconsumption of the masses which is inherent in it. A crisis could just as well be brought about by a too rapid increase in consumption, or by a static or declining production of capital goods.' Hilferding critiques Hobson's identification of contingent factors in imperialism as necessary factors. Instead, Hilferding developed the notion of disproportionality to explain the development of the latest 'phase' of capitalism.

Perhaps the first explicitly Marxist account of imperialism was Rudolf Hilferding's who, although not developing a paradigm of imperialism, laid the foundations for the Marxist understanding of the concept. ${ }^{7}$ Hilferding's imperialism was inextricably linked to the notion of monopoly; a very small group of producers of a certain commodity within a single market that is nationally constituted, as well as the unification of fractions of capital: financial, commercial and industrial capitals into finance capital controlled by bankers. This was the basic framework from which subsequent classical authors on imperialism would develop their approaches.

Hilferding (ibid.:319), describing the ultimate expression of monopoly capitalism, and the latest phase of capitalism, suggests that it is capital's reliance on the state to remove barriers to accumulation that provide the basis for imperial expansion:

'As has always been the case, when capital first encounters conditions which contradict its need for valorization, and could only be overcome much too slowly and gradually by purely economic means, it has recourse to the power of the state and uses it for forcible expropriation in order to create the required free wage proletariat' (ibid.)

This link between the nature of capitalism and the state is extremely useful in demystifying the origins of imperialism, and a step towards a theory of imperialism that springs from the nature of capitalist social relations. Hilferding also maintains that while capitalism, as a social relation, may exist everywhere, it is only when a state associated with an 'export capital' is in control of a territory that the process of surplus value extraction is at its most efficient.

'This explains why all capitalists with interests in foreign countries call for a strong state whose authority will protect their interests even in the most remote corners of the globe, and for showing the national flag everywhere so that the flag of trade can also be planted everywhere. 
Export capital feels most comfortable, however, when its own state is in complete control of the new territory, for capital exports from other countries are then excluded, it enjoys a privileged position, and its profits are more or less guaranteed by the state.' (ibid.:320)

It is this concept of export capital that binds Hilferding's concept of imperialism together. Hilferding makes it very clear that the unification of capital is only made possible through the personal relationships between influential capitalists.

'A circle of people emerges who, thanks to their own capital resources or to the concentrated power of outside capital which they represent (in the case of bank directors), become members of the boards of directors of numerous corporations. There develops in this way a kind of personal union, on one side among the various corporations themselves, and on the other, between the corporations and the bank.' (ibid.:119-120)

Subsequent to this personal union, and the creation of a new ruling class of capitalists with unified interests, Hilferding also notes a change in the relationship between individual capitalists and the state, in that it became much more intimate and direct (Brewer 1990:106). Thus, Hilferding's account is as problematic in its reliance on instrumentalism to explain the phenomenon of imperialism as Hobson's.

Bukharin (2003:152), following Hilferding, identifies that imperialism is an integral element of finance capitalism, 'without which the latter would lose its meaning'. This is problematic since it requires a periodization and typology of capitalism: when finance capitalism develops, then imperialism necessarily springs forth. Further, it requires fractionalising the state. We are unable to charitably say that Bukharin is not saying capitalism is periodisable, given his regular references to stages of capitalism, nor that he is fractionalising the state, given that he clearly states that it is at the behest of financial capital that states undertake imperialism. This paper agrees with Bukharin's first claim that imperialism 'is nothing more but a process of a continuous reproduction of the contradictions of capitalism on an ever wider scale' (Bukharin 2003:153); however, this paper cannot agree with Bukharin that this imperialism is a necessary 'stage' of capitalism or that it is caused by the domination of finance capital over the state.

Even if we consider finance capital, as Hilferding, not as a fraction of capital but rather an agglomeration of fractions of capital, it is still understood by classical imperialism that it is a monopoly capital which instigates imperialism. This remains a theory that instrumentalises the state as a mere tool of a particular group of monopoly capitalists rather than understanding the state as a form of social relations that must act in the interests of capital-in-general - to act in the interests of a particular group would be a disastrous policy and bring the general circuit of capital into crisis. In other words, it is impossible to simultaneously be a Marxist, to accept that capital only valorises through a successful completion of the circuit of capital both particularly and generally, to think that imperialism is only explicable through the logic of capitalism itself, that imperialism is only understandable as a policy instituted by finance capital's dominion over the state, and to think this is anything but a catastrophic policy that goes against the very nature of the capitalist state and the good running of the circuit of capital. It is for that reason that it is possible to distinguish Bukharin and Hobson, but it is by that reason that Bukharin indicts 
himself as presenting a flawed theory of imperialism and the state.

It would be possible to argue imperialism springs from a state that has been instrumentalised by capitalists but then one would have to argue that imperialism is always a disastrous and mistaken policy, as Hobson does, intended to benefit one particular group of capitalists. This is an empirical claim and would need to be proven on three counts: clear evidence of agential cooperation between capitalists and state managers to dominate other states would need to be found; indeed, the opposite has been found in the works of White (2000), Burnham (1990; 2003) and Kettell (2004) Further evidence would be required that one particular fraction of capital, or group of capitalists, benefits most from acts of imperialism; and one would also have to show that imperialism in every instance has been detrimental to the circuit of capital and then connect the hijacking of the normal function of the state to the sectional interests of a small group of capitalists. This viewpoint is conceptually problematic since it rests on an arbitrary division of the circuit of capital itself capital can only valorise once it has passed through each element of the circuit, and to prioritise one element over the other would be to bring the whole circuit into jeopardy (Marx 1992b).

To invoke finance capital as an explanation of imperialism is not a necessary explanation of imperialism and is conceptually problematic: either it fractionalises, and therefore instrumentalises, the state, or it periodises the state. In the work of Bukharin and Hilferding can be seen hints at historical periodization - their work rests upon a implicit periodization of capitalism by stage and development - but Lenin's treatise on imperialism makes it explicitly clear that it is a necessary and the highest stage of capitalism (McDonough 1995:355). Lenin's (2010:156) work builds further upon the work of Hilferding and Bukharin in identifying that the 'quintessence of imperialism is monopoly capital'. McDonough (1995:364) argues that Lenin's work represents the pivotal moment in resolving the 'first crisis of Marxism' as its introduction of a 'stage theory of capitalism' to Marxist thought helped to explain capitalist recovery instead of revolution.

While there are a number of similarities within the works of authors on classical imperialism, it is possible to characterize Marxists like Hilferding, Bukharin, Lenin, and Luxemburg as historical periodisers, in that they identify imperialism as a necessary stage in capitalist development. Both Hobson and Kautsky (1916:18), whose instrumentalist conception of the state is described using an analogy of a railroad whose directing engineer can be quickly changed, avoid this problem in that they consider imperialism if not a perversion of capitalism, then at least a policy undertaken by states, and, in fact, not a predetermined form of capitalism. Indeed, Lenin (2010:142) quotes Kautsky on this issue,

'Cannot the present imperialist policy be supplanted by a new, ultraimperialist policy, which will introduce the joint exploitation of the world by internationally united finance capital in place of the mutual rivalries of national finance capitals?'

Lenin vehemently disagreed with Kautsky on this point, arguing that it was inconceivable since states developed unevenly in capitalism and, therefore, national interests were constantly shifting and there could be no stable 'ultraimperialist' policy, only the conflict of the imperial stage of capital (ibid.).

The enduring value of the first theories of imperialism lies in their identification of 
the crisis prone nature of capitalism and the state's role in regulating these crises through seeking to mitigate recurrent obstacles to accumulation by means of violence and conflict (Kettell 2012:3). However, their reliance on fractionalising the state through the invocation of monopoly or finance capital, and the acceptance of the periodisation of history, reveals their mistake in identifying contingent factors as necessary factors in understanding imperialism. As such, no classical theory of imperialism provides an account of imperialism beyond the particular form it took in the time of their writing (Radice 2008:1159; Harvey 2007:58; Wood 2005:127).

\section{Neo-Colonialism: World Systems and Dependency Theories}

The 'second wave' of theories of imperialism occurred in the 1960s and 1970 s and is generally synonymous with Dependency Theory and World Systems Theory (Brewer 1990:161), and developed from Leninist ideas of uneven development (Soldatenko 1982:41). Indeed, Amin (1977:112) accepts the Leninist notion that imperialism is the highest stage of capitalism since it is the most exploitative stage of capitalism, and therefore the 'final' stage of capitalism. Where the first wave of theories of imperialism emphasised the state and rivalries between states, the theories of the second wave emphasised and argued for the importance of changes in international capitalism, the 'world system', dependency and uneven development between core and periphery states (Kettell 2012:4). ${ }^{8}$

The second wave characterised the world economy according to zones of development: core, semi-periphery and periphery with surplus value being channelled from periphery to core states. Dependency theories understand that dependent territories are kept in a perpetual state of under-development in the interests of monopoly capital in the core countries. This allows monopoly capital to continue to exploit these territories without competition from native production, and without a working class consciousness developing there. The empirical claims of this theory are tenuous, and the characterisation of development, along with the acceptance of Leninist ideas of capitalist development, requires a stage theory of capitalism (McDonough 2007:258). This characterisation leads not just to a typology of states but to a peculiar typology of class. Amin (ibid.:115) identifies core working class, and periphery working class, with their respective bourgeoisie also. They are distinct in that they are divided nationally and take on the characteristics of the bourgeoisie in their territory. As such the periphery bourgeoisie can be anti-imperialist allies to the periphery working class, so too can the core working class be pro-imperialist along with their respective bourgeoisie. This is an acceptance of the manner in which imperial relations present themselves in capitalism - not as global capitalist relations but rather as the relations between nationally constituted states.

This second wave was systemic in approach, rather than focusing on agential factors, and therefore can be said to tend to the structuralist account of the state. Considering the debt owed to Lenin by these theories, this is not surprising. The value of these approaches lies in their conceptualisation of capitalism as an inherently global social form and the emphasis upon understanding the state as a part of this system (Song 2011:293). However, the system is the focus of second wave theories of imperialism with the state analytically subordinate to the structure of international capital (Kettell 2012:4). This conceptualisation of the state and the teleological/determinist notion of development accept a species-form understanding of the state. 


\section{The New Imperialism}

The New Imperialism focuses solely on developments within the current international state system, particularly the behaviour of the United States and the concept of globalisation. While there are many authors within New Imperialism, they tend to agree that contemporary imperialism is qualitatively different to the imperialism of the $19^{\text {th }}$ and early $20^{\text {th }}$ centuries and that there now exists a new stage of imperialism, historically distinct from those that preceded it: it eschews conquest and the seizure of territory in favour of soft power and the adherence to shared values but is extremely violent. ${ }^{9}$

While classical imperialism and dependency theories both viewed imperialism as immoral, there exists a group of scholars in New Imperialism who consider the imperial role played by the United States as both benign and stabilising (Ferguson 2008; Ignatieff 2003). These approaches do not exist within a Marxist tradition but offer a radically different way of conceiving of imperialism that harks back to the late- $19^{\text {th }}$ Century idea of the 'White Man's Burden'. Such approaches tend to overemphasise the ideological justifications for imperialism and so ignore, or at least diminish, the origins of the phenomenon in violent and exploitative social relations.

Harvey's account (2003:116) of the New Imperialism provides an excellent understanding of how states seek to avoid or resolve blockages within circuits of capital, and how states act to resolve these problems. Harvey argues that if surpluses of capital cannot be put to productive use then they must be sent to another region or state to be valorised, else capital is destroyed. However, the same logic dominates in sending capital elsewhere: the 'receiving' region/state must possess means of payment or commodities to exchange. However, if this is not the case then other options must be sought.

'If the territory does not possess reserves or commodities to trade back, it must either find them... or be given credit or aid. In the latter case a foreign territory is lent or donated the money with which to buy the surplus commodities generated at home... Market and credit transactions of this sort can alleviate problems of overaccumulation within a particular territory, at least in the short term. They function well under conditions of uneven geographical development in which surpluses available in one territory are matched by lack of supply elsewhere.' (Harvey 2003:116-118)

Harvey's (2007:60) presentation of the multifarious nature of state action within global capitalism is useful in developing a theory of imperialism, and goes some way towards presenting an open understanding of inter-state relations in global capitalism. While Harvey's account here suggests that imperialism is timeless and not periodisable, his account of capitalism entering a post-modern stage with radical changes occurring in the global economy in the 1970s, and of contemporary examples of imperialism being somehow qualitatively 'new', and particularly his focus on the United States, are difficult to reconcile with an OM approach.

New Imperialism's focus on the United States is certainly understandable but is also critiqued from within. Hardt and Negri (2000) term contemporary imperialism as 'Empire' and criticise the American-centric approach of both Harvey and Ignatieff. ${ }^{10}$ To Hardt and Negri (ibid.:xii), Empire is a new form of sovereignty: a decentralised and deterritorialised global power structure within which no state, not even the United States, can be the centre 
of an imperial system. To them, 'imperialism is over' (ibid.:xiv). Their conception of Empire has four key points: firstly, Empire encompasses the entire world; secondly, Empire represents itself as existing in perpetuity; thirdly, Empire operates on all levels of society; fourthly, Empire is a bloody business but represents itself as a perpetual peace (ibid.:xv). While Empire offers a compelling argument for a contemporary understanding of imperialism, it is, in effect, a synonym for capitalism and offers very little beyond that characterisation (Kiely 2005:48). This critique is also made by Wood (2002; 2005:6) of both Bobbitt (2002) and Hardt and Negri (2000), who she argues accept the superficial qualities of globalisation and miss something 'truly essential' about both capitalism and imperialism, namely a robust understanding of the state.

Conversely, Pozo-Martin (2006:236), Panitch and Gindin (2006) and Robinson (2007:8) point out that other scholars of the New Imperialism, including Gowan (1999), Harvey (2003) and Callinicos (2005a; 2005b), have created a Realist theory of international relations, using notions of national capitals and interest, hybridised with a Marxist understanding of imperialism, despite the two having incompatible approaches to the state and society. While the New Imperialism's abandonment of instrumentalism is an admirable move for a theory of imperialism, it is not replaced with a robust idea of the state's relationship with capital (ibid.). Indeed, Pozo-Martin (ibid.:237) criticises Harvey (2003) and Callinicos (2005b) particularly for their acceptance of a Realist logic of international relations based upon 'the weakening lack of any substantive Marxist theory of the state'. Callinicos' $(2010: 82-4)$ response to this is to invoke the OM conception of the state, as a means of rejecting the reified Realist understanding of the state while still conceiving of a global state system as essentially capitalist in nature. However, Callinicos (ibid.) rejects the formanalysis of the state as useless, which leads him ultimately to accept a 'broadly Gramscian approach' to imperialism (ibid.:99) and so able to periodise history according to apparent discontinuities in social and state form (ibid.:138).

The New Imperialism offers a diverse analysis of the 'new' developments in the international state system in the late $20^{\text {th }}$ Century. However, here lies the inherent problem: while there is ambiguity over when it began, ranging from the end of the Second World War to the end of the Cold War, the new imperialism maintains that global society has entered a qualitatively new stage of imperialism and capitalism. Hardt and Negri's (2000) conception of this capitalism is based on an acceptance of Harvey (2003) and Jameson's (1991) arguments that capitalism has entered a postmodern stage. This is also true of Wood (2005:134) who argues that the new imperialism rests on a 'Universal Capitalism' - one in which capitalism has already expanded to incorporate the entire globe, requiring a new type of imperialism based on 'economic domination' rather than the rivalry of nation states that characterised 'old imperialism'. Harvey (2007:60) criticises Wood's (2005:100) typologies of both imperialism and capitalism as unable to fully explain the dynamic changes in global capitalism. Harvey (2007:67) acknowledges that neither he nor Wood (2005) did a 'very good job' of theorising the state in their accounts of imperialism, which incites him to exhort, 'Not only do we need a new theory of imperialism to match the conditions of our time but we also need a new theory of the capitalist state'. The New Imperialism is irreconcilable with $\mathrm{OM}$ by virtue of its explicit acceptance of a stage theory of capitalism and the periodization of history.

\section{Towards a Theory}


The intention of this paper is not, as David Harvey (ibid.:60) cautions, to conceptualise a new imperialism but to seek to make consonant a theory of imperialism with the extant OM theory of the state and the inter-state system. As Hae-Yung Song (2011:292) points out, the OM account of the global political economy is not intended to explain the extant unevenness of global capitalism but rather to 'to point out the hierarchical and uneven ways in which 'national' economies subsist in and through the world market, which gives rise to the notion itself that the state is (and actually appears) as the embodiment of 'national interests' against the world market'. This then permits OM to ask what about the nature of the inter-state system causes hierarchical relationships to develop (ibid.:293). While Song moves on to argue that a world-system analysis can complement OM to produce a satisfying account of the uneven development of national economies, this paper has already argued that a world-system analysis is incompatible with an OM understanding of social relations.

The literature on inter-state competition within OM does not explicitly discuss imperialism, other than to dismiss traditional approaches as indulgences in historical periodization (Clarke 1992:149). As with the state, the issue between form-species and form as mode-of-existence can be applied to the concept of imperialism. As other Marxist authors have used the concept of imperialism, they have often understood imperialism as a 'species' of capitalism, thus turning it into a 'stage' of capitalism, or even into a 'type' of state. OM, in its application of form as mode-of-existence, avoids this dilemma:

'Once the relation between structure and struggle is seen in terms of form as mode-of-existence one can never return to ideas of the development of capitalism on the basis of distinct stages... (as in Lenin)... Dialectics comes into its own as the critique of, precisely, such a division into stages. Critique comes into its own dialectically, as inherent in the movement of contradiction and, so, an open Marxism is able to demystify the notion of times in a forceful way' (Bonefeld et al., 1992a:xvii)

The language, logic and argument are present within the literature to easily draw out an idea of imperialism that is consonant with OM. It is necessary to understand the relations between states in order to typify and understand the phenomenon of imperialism.

If we take the state to be a form of capitalist social relations, then we can conclude that its survival requires the continuation of these relations, 'it is therefore not just a state in a capitalist society, but a capitalist state, since its own continued existence is tied to the promotion of the reproduction of capitalist social relations as a whole' (Holloway 1994:28). However, it is not the case that a national state can exist simply on the reproduction of global capital, capital reproduction must occur within its territory (ibid.:34). The focus must be on the relation of capital to the national state. As Holloway (ibid.:33) observes, this 'is a relation of a nationally fixed state to a globally mobile capital'. Since capital is inherently mobile, states must seek it out in order to immobilise it, they must actively promote conditions favouring the reproduction of capital as they derive both wealth and power from it (Burnham 1995; 2006). Indeed, as Burnham (1995:104) notes, a number of unequal relationships characterise the international state system from competition to collaboration. With the world economy driven by the basic logic of capitalism to accumulate, so too do states seek to reproduce the conditions for accumulation on ever greater scales (ibid.:105i Holloway 1994:34). This is the basis for the phenomenon of imperialism. 
Certain theories conceived of states exploiting each other, thus creating 'classes' of states: core and periphery states. ${ }^{11}$ This is a conclusion that stems from an analysis that takes the view of states as political entities exogenous to capitalist social relations and autonomous from capital - the state in capitalist society; this divorces the political from the economic and denies the logic of the state as a capitalist state. ${ }^{12}$ As Bonefeld (2008:70) points out, in critique of social democracy, arguments concerning the relative autonomy of the state rest fundamentally on the analytical separation of the political and economic, which is itself based on a theoretical distinction between production and distribution, and the primacy of the latter over the former. As such, the 'capitalist concern for profit transformed into the national interest in economic growth' and so the social democratic strategy of statecraft, while certainly improving conditions for labour, retains its bourgeois character as a form of capitalist social relations (ibid.).

Through understanding the essential unity of the capitalist social form, and the state as a political moment within the capitalist mode of production, it becomes clear, as Holloway (1994:34) notes, that the competition between the specific national forms of the state is not, as previous theories of imperialism have characterised them, as competitions between national capitals but rather it is a contest to attract and then immobilise capital within their territories so as to retain a share of global surplus value. This can take the form of acting to develop conditions that favour the reproduction of capital within the boundaries of a state but, also, 'capital may accumulate in the territory of one national state as the result of the exploitation of labour in the territory of another' (ibid.:35). Ultimately, this is how relative positions within the inter-state system are formed; relationships of supremacy and subordination are founded upon a state's ability to attract and immobilise capital within its territory.

Having acknowledged the importance placed upon the circuit of capital by an OM analysis, through the identification of constraints placed upon state managers, Burnham (2006:79) identifies that the circuit of capital itself is not simply a national phenomenon but 'exists as part of a set of global relations' and thus it 'directs our attention to the importance of international economic rules and political arrangements. The operation of the circuit may, for instance, be enhanced for one state, if other state managers can be drawn into cooperative economic arrangements, such as dollar pooling in conditions of scarcity, the rescheduling of debts (sterling balances policy) or in collective moves to realign exchange rate policy and re-establish the convertibility of currencies'. Burnham's point here highlights the role an imperial strategy can play in mitigating crisis, and removing blockages in the circuit of capital both domestically and globally. Burnham (ibid.; 2001b) also points out that, while all states are fundamentally capitalist states, they are not all able to adopt the same strategies or be as successful in their implementation, due to the particular historical relationships held between individual national states and global capital. ${ }^{13}$

As Kettell (2012:13) notes, 'the imperialist impulse, and hence the specific form in which it becomes manifest, needs to be examined as a strategic choice; a set of decisions made in the nexus of state managerial goals and perceptions, domestic conditions, and the particular relationship between the state and the wider context of the global environment'. Imperialism then is the action of one state to dominate another to its own advantage. It is not a historical period of capitalism, nor a type of state, nor is it something that can be constituted only as a formal empire (Gallagher \& Robinson 1953:1). The origin of imperialism lies in the crisis-prone nature of capitalism, as an attempt by one state to improve 
conditions for accumulation within its own territory, as a means of removing barriers to accumulation by foreign adventure.

The abstractions within OM are essential in understanding the problems that beset governments and state managers; however, these can only truly be revealed by close analysis of state managers at particular moments in history. Indeed, as Burnham (2006:81) notes, 'the value that a Marxist approach can bring to such a historical analysis... is that it can... construct and reconstruct the circuit of capital, abstracting and recombining elements of the circuit to ultimately relate an abstract discussion of state and capital to the activities of say the Overseas Finance [Division] of the Treasury in February 1952.'

The value of a Marxist approach is in its focus on the dynamic nature of society and the changing forms that spring from the central contradictions of capitalist social relations (Willoughby 1995:329). However, that has not been successful with Marxist theories of imperialism that have either posited stage theories of capitalism, or have been overturned by new developments in the international political economy. Classical Marxist theories of imperialism sought to explain through the nature of capitalism itself how the specific events of imperialism and the imperialist wars of the $19^{\text {th }}$ and $20^{\text {th }}$ centuries occurred. However, while many factors are important in their analysis, their conclusions have been proven flawed and their assumptions that the particular forms of inter-state rivalry, and the development of monopoly capital, follow necessarily from capitalism are unfounded. These are contingent factors and, while consonant with the logic of capitalism, they are not necessary developments from them.

The OM account of imperialism then must draw its analysis and conclusions from the essence of capitalism within imperialism. While Lenin famously claimed that the fundamental essence of imperialism is monopoly capitalism, OM must disagree - the essence of imperialism is the capitalist state, the logic of imperialism is the logic of the capitalist state. The capitalist state acts in the interests of capital-in-general and seeks to remove blockages to the circuit of capital, processing this nationally but also internationally (Burnham 1995; 2006). An imperial relationship is an unequal relation between states within which the dominating state has hijacked the capacity of the dominated state to act in its own national interest. It has appropriated the state's processing capacity for its own ends. Where historically this occurred as a means of ensuring the export of unproductive surplus capital, it now takes the form of methods to ensure the continued attractiveness of the US to mobile capital, and its continued dominance of the global political economy - this has meant imperial wars in the Middle East and Central Asia, as well as the structuring of international financial architecture to favour accumulation in and through the US.

Prior theorists of imperialism have tended to make necessary the contingent factors of imperialism during their time of writing, hence 'stages' of imperialism, humanitarian intervention, monopoly capital, 'core' and 'periphery' states, 'under-development' and dependency, globalisation. These are mere historical contingencies and, while certainly they are forms of imperialism, they are no more revealing about the nature of imperialism than typologies of states are for the nature of the capitalist state. The options available to states in pursuing imperial endeavours, or establishing imperial relationships is wide indeed but the only means by which this can be understood through OM, that is by synthesising the general and particular, and the abstract and concrete, is to identify these as forms through which imperialism manifests. 


\section{Conclusion}

This paper has sought to move towards an OM theory of imperialism by characterising prior theories of imperialism as valuable in identifying the salient points of imperialism but ultimately dissonant with open Marxism's ideas of state and society.

The paper offered an overview of $\mathrm{OM}$, which provided an account of the state as a form of social relations, best understood in capitalist society as a concentration of bourgeois society, or as a political 'moment' within global capitalist social relations. This sees the state acting in the interests of capital-in-general to resolve crises and blockages within the circuit of capital. The state acts to reproduce capitalist social relations, as this is the constitution of its form.

OM's means of achieving these conclusions prohibits the understanding of the state by any means that alienates the abstract from the concrete or the political from the economic, thus avoiding typologies of states. The use of the concept of form also prohibits the division of capitalism into stages. Therefore notions of imperialism cannot consider imperialism as a stage of capitalism. As such, this paper has identified that the factors marked as imperialism within older and even more recent ideas of imperialism are historically contingent and not essential to understanding the phenomenon of imperialism itself. These are manifestations of imperialism but these forms of imperialism can only be understood in terms of the essence of capitalist social relations, the nature of the capitalist state, and the open character of society.

The origins of capitalist imperialism must lie in the nature of the capitalist state. Imperialism originates as a means by which the state seeks to dissolve a blockage in the circuit of capital, as represented to state managers through the conditions imposed upon their decision-making by domestic constraints and the global capitalist economy. Imperialism springs from the exploitative and eternally expansionary nature of capitalism and its tendency to crisis (Clarke 1994; 1999). Imperialism is then best understood as a strategy of a state intended to resolve crises emerging from the unstable and fractious nature of capitalism through the domination of another state's particular capacities to process the circuit of capital. The paper rejects the idea that one state can exploit another; however, this paper does accept that one state can dominate or influence another's policies and affairs to benefit its own, and to resolve the crises that beset the circuit of capital. This does not entail a 'one-way' understanding of imperialism and accepts that a state can benefit from imperial domination. This provides an account of imperialism that does not offer an austere conception of imperial activity. ${ }^{14}$ While conditioned by the task of state managers to ensure the success of capital valorisation both domestically and internationally, an imperial relationship still remains an open and dynamic relationship that is characterised by both opportunities and constraints that limit the behaviours of all states involved.

Critiques of OM concerning its alleged over-abstraction tend to focus on the perceived greater value of abstractions in other theories: the periodisations and typologies that their basic assumptions permit. OM critiques these assumptions, and shows periodization and typologies of states to be highly problematic, and so, without these particular abstractions, $\mathrm{OM}$ is critiqued as being 'too abstract' or operating at a level of such abstraction that it is not an useful social theory (Bieler \& Morton 2003; Bruff 2009a, 2009b; 
Bieler, Bruff \& Morton 2010). However, this critique rests on the assumption that OM denies that there is any difference between states. On the contrary, $\mathrm{OM}^{\prime}$ 's critique intends to annihilate the problematic abstract 'middle-ground' of periodisation and typology thus to deny there is a difference between states as capitalist states, but not between state actions or strategy. As such the focus of enquiry is not the type of state, or the particular contingencies of history identified as necessary components of it, but rather the strategies states undertake to ensure the completion of the circuit of capital, on a national and global basis.

This identification thus requires an understanding of strategies such as imperialism and depoliticisation but these can only be understood in terms of the logic of the capitalist state, not identified as the 'imperial state' or the 'neo-liberal state'. Instead, these are strategies that can be understood as 'statecraft' (Burnham 2001b:136; Bulpitt 1996:225). Thus, for example, depoliticisation is an attempt by state managers to reduce their exposure to the accountability of economic policy-making, or rather understood 'as the process of placing at one remove the political character of decision-making', and can therefore be understood in terms of the fundamental logics and contradictions of the capitalist state, so too can imperialism be understood as a strategy which states engage in to avoid or mitigate extant or incipient crises of capitalism (Burnham 2001b:136).

One final implication of this analysis lies in the possibility for further empirical applications of OM, which are currently few. These studies tend to focus solely on the British state in the $20^{\text {th }}$ century and use the concept of depoliticisation to apply the ideas of OM to a case study (Burnham 1990, 2003; Kettell 2004; Rogers 2012). This has been the subject of comment by Bieler, Bruff \& Morton (2010) but is an opportunity rather than a criticism. The use of imperialism presents another means by which OM can be applied to understanding the historical nature and contours of the global economy and the limits of and opportunities for state action within it.

\footnotetext{
${ }^{1}$ I would like to thank Chris Clarke and Pinar Donmez for reading and providing advice on earlier drafts of this paper. I am also grateful to the two anonymous reviewers for their very helpful comments.

${ }^{2} \mathrm{OM}$ is a diverse approach and can perhaps best be termed as a 'school' than a clear and unambiguous theory of social relations. For a more substantial analysis of the OM approach see, inter alia, Bonefeld et al. (1992a; 1992b; 1995), Bonefeld and Psychopedis (2001), Bonefeld and Holloway (1991; 1995), Burnham (1991; 2001; 2006), Clarke (1994; 1999). For the origin of the term 'open Marxism', see Mandel and Agnoli (1980). For critique of the approach, see, inter alia, Bieler and Morton (2003), Bieler et al. (2006), Bruff (2009a) and (2009b), Bieler, Bruff and Morton (2010) and Tsolakis (2010).

${ }^{3}$ Ray Kiely (2005:53) argues that the rejection of historical periodization within capitalism is unconvincing, identifying $\mathrm{OM}$ as a particular culprit. However, he does not develop this point and so it remains unsubstantiated. He does admit that the debate over historical periodization lies out of the scope of his paper. This paper, however, sees the debate over historical periodization as essential to understanding imperialism and social form. While Kiely (2005:50) does emphasise the importance of identifying the contingent nature of social form and that any approach must recognize the essential openness of social relations, he too relies on the explanatory value of historical periodization and on the typology of states to understand imperialism (ibid.:49-51).

${ }^{4}$ Callinicos (2010:84 cites Barker's (1978:4) critique of state form-analysis. While Callinicos (2010:84) accepts the strength of an OM approach in identifying the fetishized nature of the capitalist state, he dismisses it as ultimately useless in understanding different state strategies for accumulation due to
} 
its abstract nature. This is a strawman argument since form-analysis rejects only typologies of states, rather than a plurality of state strategies within capitalism. Callinicos' (ibid.) objection to OM, with the assertion that China has a different strategy to accumulation than the United States, does not obtain. Furthermore, an OM theory of imperialism must necessarily accept that not all states pursue the same strategies as not all states engage, or have engaged, in imperialism but it does not follow that there is an 'imperialist-type' of state. As both Kettell (2004) and Burnham (1990; 1995) note, it is the existence of nationally-constituted states as political nodes for the processing of the global circuit of capital, that leads to the existence of diverse strategies for capital accumulation but this does not alter the organization of the state form as a capitalist state.

${ }^{5}$ Hobson's description of those who control financial capital is anti-Semitic.

${ }^{6}$ Under-consumption here is best understood as a choice made by consumers not to purchase but to save their money and therefore it is not inherent to capitalist social relations. Overproduction is understood as an inherent tendency within capitalist social relations to produce more goods than can ultimately be consumed. This characterizes Hobson's conception of under-consumption as a crisis exogenous to capitalism.

${ }^{7}$ While Hilferding's approach laid a foundation for an analysis of imperialism, his approach focuses on the unification of capital within the 'metropolis' rather than on an analysis of relationships between states. It is Bukharin and Lenin who develop 'theories' of imperialism, though their reliance on Hilferding's work is clear.

${ }^{8}$ See, inter alia, Cohen (1973), Wallerstein (1974; 1975; 1980; 1989), Amin (1977), Frank (1978; 1980), Frank \& Gills (1993), Arrighi (1994).

${ }^{9}$ There is a lack of clarity in the literature over where the novelty of 'new imperialism' actually lies: is it a description of a qualitatively different imperialism as it exists today, a new approach to the study of imperialism, or both (Kettell 2011; 2012:6-20)? Harvey (2007:57) also acknowledges this ambiguity and remarks that different obligations rest on either interpretation: if the former, then new concepts and ideas have to be marshalled to explain it in addition to a re-evaluation of older theories of imperialism; if the latter, then this new way of thinking must take into account older ideas, as well as apparent radical changes in the material conditions of imperialism and the global economy. While there is an ambiguity over the origins and meaning of the term, the analytical and intellectual obligations stemming from either are very similar.

${ }^{10}$ Antonio Negri has written within OM scholarship, and is a proponent of autonomist Marxism with which OM is associated. His work in Empire represents a continuity with certain themes within OM, particularly notions of capitalism as an inherently global social form, but significantly dissonant in other regards, particularly his rejection of the state as a unit of analysis in imperialism.

${ }^{11}$ For example, Lenin (1934), Wallerstein (1974), Frank (1979)

${ }^{12}$ As Holloway (1994:35) notes, 'exploitation is not the exploitation of poor countries by rich countries but of global labour by global capital, and the bipolarity is not a centre-periphery bipolarity but a bipolarity of class, a bipolarity in which all states, by virtue of their very existence as states dependent on the reproduction of capital, are located at the capitalist pole.'

${ }^{13}$ Radice (2008:1170) makes a good point that the state is essential in aiding the capitalist class in overthrowing earlier forms of social relations, and consolidating capitalist social relations: 'the use of state force to wrest resources away from groups not disposed to capitalist accumulation; the formation of the state itself, and the capacity to contain divergent internal interests...and defend insiders against predatory external forces; these are part and parcel of how, historically, states and societies have become capitalist'. However, while Radice (ibid.) emphasizes that this understanding of the state should be tied to the concept of class struggle, he is eager to use the conceptual framework of the developmental state, a type of state that he identifies with the move from precapitalist to capitalist societies, to understand capitalist development and the global economy. His points concerning the relevance of class struggle and the nature of the capitalist state are valuable but his typology of states is problematic, and not consistent with an OM analysis. While he is critical of the developmental state, denying it has any emancipatory agenda, he accepts a typology of 
states.

${ }^{14}$ As such, an OM theory of imperialism can account for the variety of 'imperialisms' that have existed: holding territory, influencing political and economic decisions, extracting resources, preparing states for absorption into global capitalism through development, as a location for the consumption of unproductive capital, and the control of particularly important markets and goods. 


\section{References}

Amin, Samir (1977) Imperialism and Unequal Development Monthly Review Press New York

Arrighi, Giovanni (1994) The Long Twentieth Century: Money, Power, and the Origins of our Time Verso London

Barker, Colin (1978) A Note on the Theory of Capitalist States Capital and Class 4

Bieler, Andreas, lan Bruff \& Andrew David Morton (2010) Acorns and Fruit: From Totalisation to Periodisation in the Critique of Capitalism Capital \& Class 34:1

Bieler, Andreas, Werner Bonefeld, Peter Burnham and Adam David Morton (eds.) (2006) Global Restructuring, State, Capital and Labour: Contesting Neo-Gramscian Perspectives Palgrave London

Bieler, Andreas \& Adam David Morton (2003) Globalisation, the state and class struggle: a 'Critical Economy' engagement with Open Marxism British Journal of Politics and International Relations 5:4

Bobbitt, Philip (2002) The Shield of Achilles Allen Lane Penguin London

Bonefeld, Werner (2008) Global Capital, National State and the International Critique: Journal of Socialist Theory 36:1

Bonefeld, Werner (2006) Human Progress and Capitalist Development in Bieler, Andreas, Werner Bonefeld, Peter Burnham and Adam David Morton (eds.) Global Restructuring, State, Capital and Labour: Contesting Neo-Gramscian Perspectives Palgrave London

Bonefeld, Werner and Kosmas Psychopedis (eds) (2001) The Politics of Change: Globalization, Ideology and Critique Palgrave Hampshire

Bonefeld, Werner and John Holloway (eds) (1995) Global Capital, National State and the Politics of Money Macmillan London

Bonefeld, Werner, Richard Gunn, John Holloway and Kosmas Psychopedis (eds) (1995) Open Marxism Volume III: Emancipating Marx Pluto Press London

Bonefeld, Werner, Richard Gunn and Kosmas Psychopedis (eds) (1992b) Open Marxism Volume II: Theory and Practice Pluto Press London

Bonefeld, Werner, Richard Gunn and Kosmas Psychopedis (eds) (1992a) Open Marxism Volume I: Dialectics and History Pluto Press London

Bonefeld, Werner and John Holloway (eds) (1991) Post-Fordism and Social Form: A Marxist Debate on the Post-Fordist State Macmillan, London

Bradley, F H (1930) Appearance and Reality Oxford University Press Oxford

Brewer, Anthony (ed) (1990) Marxist Theories of Imperialism: A Critical Survey Routledge London

Bruff, Ian (2009b) The Totalisation of Human Social Practice: Open Marxists and Capitalist 
Social Relations, Foucauldians and Power Relations British Journal of Politics and International Relations 11:2

Bruff, Ian (2009a) Assertions, Conflations and Human Nature: a Reply to Werner Bonefeld British Journal of Politics and International Relations 11:3

Bukharin, Nikolai (2003) Imperialism and World Economy Bookmarks London

Bulpitt, Jim (1996) The European question in David Marquand and Anthony Seldon (eds) The Ideas That Shaped Post-War Britain Fontana London

Burnham, Peter (2006) Marxism, the State, and British Politics British Politics 1

Burnham, Peter (2003) Remaking the Postwar World Economy: Robot and British Policy in the 1950 Palgrave Macmillan London

Burnham, Peter (2001b) New Labour and the Politics of Depoliticisation British Journal of Politics and International Relations 3:2

Burnham, Peter (2001a) Marx, International Political Economy and Globalisation Capital and Class 75

Burnham, Peter (1995) Capital, Crisis and the International State System in Werner Bonefeld and John Holloway (eds) Global Capital, National State and the Politics of Money Macmillan London

Burnham, Peter (1994) The Organisational View of the State Politics 14:1

Burnham, Peter (1991) Neo-Gramscian Hegemony and the International Order Capital and Class 45

Burnham, Peter (1990) The Political Economy of Postwar Reconstruction Macmillan London

Callinicos, Alex (2010) Imperialism and Global Political Economy Polity Cambridge

Callinicos, Alex (2005b) Iraq: Fulcrum of World Politics The Third World Quarterly 26:4

Callinicos, Alex (2005a) Imperialism and Global Political Economy International Socialism 108

Clarke, Simon (1999) Capitalist Competition and the Tendency to Overproduction: Comments on Brenner's 'Uneven Development and the Long Downturn' Historical Materialism 4:1

Clarke, Simon (1994) Marx's Theory of Crisis Macmillan, London

Clarke, Simon (1992) The Global Accumulation of Capital and the Periodisation of the Capitalist State Form in Werner Bonefeld, Richard Gunn and Kosmas Psychopedis (eds.) Open Marxism Volume I: Dialectics and History Pluto Press London

Clarke, Simon (ed.) (1991) The State Debate Macmillan London

Cohen, Benjamin J (1973) The Question of Imperialism: The Political Economy of 
Dominance and Dependence Macmillan London

Ferguson, Niall (2008) Colossus: The Rise and Fall of the American Empire Penguin London

Frank, Andre Gunder and Barry Gills (eds.) (1993) The World System: Five Hundred Years of Five Thousand? Routledge London

Frank, Andre Gunder (1980) Crisis in the World Economy Holmes \& Meier New York

Frank, Andre Gunder (1978) Dependent Accumulation and Underdevelopment Macmillan London

Gowan, Peter (1999) The Global Gamble Verso London

Hardt, Michael \& Antonio Negri (2000) Empire Harvard University Press London

Harvey, David (2007) In What Ways is 'The New Imperialism' Really New? Historical Materialism 15

Harvey, David (2003) The New Imperialism Oxford University Press Oxford

Harvey, David (1999) The Limits of Capital Verso Books London

Hilferding, Rudolf (1981) Finance Capital: A Study of the Latest Phase in Capitalist Development Routledge London

Hobson, John A (1968) Imperialism - A Study Allen \& Unwin London

Holloway, John (1995) From Scream of Refusal to Scream of Power: The Centrality of Work, in Werner Bonefeld, Richard Gunn, John Holloway \& Kosmos Psychopedis (eds.) Open Marxism Volume III: Emancipating Marx Pluto Press London

Holloway, John (1994) Global Capital and the State Capital and Class 52

Holloway, John and Sol Picciotto (1977) Capital, Crisis and the State Capital and Class 2

Ignatieff, Michael (2003) Empire Lite: Nation-Building in Bosnia, Kosovo, Afghanistan Vintage Books London

Jameson, Fredric (1991) Postmodernism, or The Cultural Logic of Late Capitalism Verso London

Kautsky, Karl (1916) The Social Revolution Charles H Kerr Chicago

Kettell, Steven (2012) New Imperialism: Towards a Holistic Approach (manuscript submitted for publication)

Kettell, Steven (2011) New Labour and the New World Order: Britain's role in the war on terror Manchester University Press Manchester

Kettell, Steven (2004) The Political Economy of Exchange Rate Policy-Making: From the Gold Standard to the Euro Palgrave Macmillan Hampshire

Kiely, Ray (2005) Capitalist Expansion and the Imperialism-Globalisation Debate Journal of 
International Relations and Development 8:1

Lenin, V I (2010) Imperialism: The Highest Stage of Capitalism Penguin Books London

Luxemburg, Rosa (translated by Agnes Schwarzchild) (1963) The Accumulation of Capital Routledge London

Mandel, Ernest \& Johannes Agnoli (1980) Offener Marxismus: ein Gespräch über Dogmen, Orthodoxie und die Häresien der Realitätl Frankfurt/New York

Marx, Karl (1992b) Capital: A Critique of Political Economy, Volume II (translated by Ernst Mandel) Penguin Books London

McDonough, Terrence (2007) The Marxian Theory of Capitalist Stages in Paul Zarembka (ed) Transitions in Latin America and in Poland and Syria Research in Political Economy 24 Emerald Group Publishing Ltd

McDonough, Terrence (1995) Lenin, Capitalism, and the Stages of Capitalist Development Science and Society 59:3

Panitch, Leo and Sam Gindin (2006) Feedback: Imperialism and Political Economy - a Reply to Alex Callinicos International Socialism 109

Pozo-Martin, Gonzalo (2006) A Tougher Gordian Knot: Globalisation, Imperialism and the Problem of the State Cambridge Review of International Affairs 19:2

Radice, Hugo (2008) The Developmental State under Global Neoliberalism Third World Quarterly 29:6

Robinson, William I (2007) Beyond the Theory of Imperialism: Global Capitalism and the Transnational State Societies without Borders 2

Rogers, Christopher (2012) Managing Financial Crises: The IMF and Advanced Economies since 1976 Palgrave Basingstoke (forthcoming)

Song, Hae-Yung (2011) Theorising the Korean State beyond Institutionalism: Class Content and Form of 'National Development' New Political Economy 16:3

Soldatenko, Michael (1982) An Overview of Development Theories South Asia Bulletin 2:2

Tsolakis, Andreas (2010) Opening Up Open Marxist Theories of the State: A Historical Materialist Critique British Journal of Politics and International Relations 12:3

Wallerstein, Immanuel (1989) The Modern World-System, Volume Three: The Second Great Expansion of the Capitalist World-Economy 1730-1840 Academic Press New York

Wallerstein, Immanuel (1980) The Modern World-System, Volume Two: Mercantilism and the Consolidation of the European World-Economy 1600-1750 Academic Press New York

Wallerstein, Immanuel (1975) World Inequality: Origins and Perspectives on the World System Spokesman Nottingham

Wallerstein, Immanuel (1974) The Modern World-System, Volume One: Capitalist 
Agriculture and the Origins of the European World-Economy in the Sixteenth Century Academic Press New York

White, Nicholas (1996) Business, Government, and the End of Empire: Malaya 1942 - 1957 Oxford University Press Oxford

Wood, Ellen Meiksins (2005) Empire of Capital Verso London

Wood, Ellen Meiksins (2002) The Origins of Capitalism: A Longer View Verso London 